\title{
Economic aspects of multiple myeloma: real costs associated with disease in the Slovak Republic
}

\author{
Robert BABELA ${ }^{1, \star}$, Richard DIDIC ${ }^{2}$, Martin SMATANA $^{3}$, Katarina FEDOROVA ${ }^{4}$, Lubos DRGONA ${ }^{5}$ \\ ${ }^{1}$ NOI and Institute for Healthcare Disciplines, St. Elizabeth University, Bratislava, Slovakia; ${ }^{2}$ Institute for Healthcare Disciplines, St. Eliza- \\ beth University, Bratislava, Slovakia; ${ }^{3}$ Slovak Patients Association, Bratislava, Slovakia; ${ }^{4}$ Faculty of Law, Trnava University, Trnava, Slovakia; \\ ${ }^{5}$ National Cancer Institute, Bratislava, Slovakia
}

${ }^{*}$ Correspondence: babela@seuniversity.eu

Received November 3, 2020 / Accepted December 27, 2020

\begin{abstract}
Health care costs are continuously increasing. Multiple myeloma represents approximately $1 \%$ of all malignancies and the 5-year prevalence is 230,000 patients on average. In addition, there is an annual incidence of 3.8/100,000 in Slovakia. In total economic burden assessment, it is important to focus not only on direct but also on indirect costs, including the lost productivity due to premature death. Based on the data and information obtained from the key stakeholders the Ministry of Health, the Ministry of Labor, the Social Insurance Agency, and NCZI, we provided the assessment of direct and indirect costs. The total cost of the disease for the model patient represents $€ 409,071$ from the diagnosis of MM to death. The major cost burden is associated with the treatment, $€ 155,645$ followed by the costs of productivity loss due to premature death, $€ 127,611$. Cost-of-illness studies provide an important view on the total burden of the disease in specific areas and are necessary for an adequate decision-making process from the regulatory and reimbursement perspective.
\end{abstract}

Key words: multiple myeloma, cost-of-illness, direct costs, indirect costs, burden of disease

The expenses on healthcare are constantly rising. The protocols for diagnostics and treatment of a variety of diseases are more sophisticated, containing various possibilities of medical imaging, new surgical practices, new drugs and all this together leads to continual increases in costs. Diagnostics and treatment of patients with multiple myeloma (MM) represent no exception [1].

Worldwide, the MM accounts for approximately $1 \%$ of all cancers and is the 2nd most common hematologic malignancy with an estimated 24,280 to 30,330 new cases and 12,650 deaths to occur for 2016 [2-5]. Additionally, the 5 -year prevalence is approximately 230,000 patients [6]. In the Western world, the age-standardized incidence has been reported to be approximately 5 cases $/ 100,000[7,8]$. The median age of patients at diagnosis is approximately 66-70 years with $37 \%$ of patients being younger than 65 years of age $[3,9]$. MM is extremely rare in those less than 30 years of age with a reported frequency of $0.02-0.30 \%$ and appears to occur slightly more frequently in men $[10,11]$.

Epidemiology of multiple myeloma. The data describing the epidemiology of multiple myeloma (MM) in Slovakia are considerably inaccurate. The raw data are provided by the National Cancer Registry, the problem is that these contain data from the entire range of diagnosis according to the MKCH (International Classification of Diseases in English), specifically C81-C96. In 1997, 540 men and 564 women were treated for this particular group of diagnoses, which cumulatively consisted of 1,104 patients. In 2004, this group occurred among 656 men and 675 women. However, in 2011, the incidence was much higher; specifically, it was found among 1,122 men and 1,071 women, which cumulatively represented 2,193 patients. It can be assumed that 3,037 patients will be treated for this given group of diagnoses by 2030 [12]. Based on the NCZI data, there were 844 cases of MM in Slovakia between 2000-2016, of which 55\% were women and $45 \%$ men. The highest incidence was observed in 2014, especially in 140 cases [12].

The same register lists 4,826 cases of MM in the Czech Republic in the monitored period, of which $48.2 \%$ were women and $51.8 \%$ men. The highest incidence was observed in 2013, especially in 490 patients according to Sakalová et al. [13], there is an annual incidence of 200-300 new cases in the Slovak Republic $(3.8 / 100,000)$. In comparison to the Czech Republic, the incidence of multiple myeloma is 2.62 among men and 2.55 among women/100,000 inhabitants [14]. It is a disease of the elderly; in the age group of 75-79 years, the 
incidence of this disease is $15.57 / 100,000$ inhabitants [14]. Among young people aged $20-40$, the disease occurs rarely [14].

When comparing the incidence of particular tumors from the total number of newly reported malignancies in the Slovak Republic in the period 2001-2005, MM (3.8/100,000 inhabitants) was the one with the 4 th lowest incidence since Hodgkin's lymphoma (2.4), thyroid tumors (1.8), and breast tumors (0.7) had all lower incidence per 100,000 inhabitants.

Among women, it was a tumor with the 6th lowest incidence per 100,000 inhabitants (3.2) during the examined period because Hodgkin's lymphoma (2.6), tumors of lips, oral cavity and pharynx (3.2), liver tumors (2.8), esophagus (0.8), and larynx (0.5) had all lower incidence per 100,000 inhabitants [15]. In general, MM is not considered to be a genetic disease, however familial cases, albeit rare, do exist [16]. Patients with multiple myeloma usually present bone marrow infiltration of clonal plasma cells and monoclonal protein in the serum and/or urine. Significant progress has been made over the past decade in the understanding of disease biology and individualized treatment approaches. Several new classes of drugs (proteasome inhibitors, immunomodulatory drugs) have joined the traditional standard treatment options (e.g., corticosteroids) and, along with high-dose therapy and autologous hemopoietic stem cell transplantation, have led to deeper and durable clinical responses [17-19]. By developing new innovative technologies and approaches, the costs reached even higher levels [1]. Multiple myeloma is still a non-curable malignant disease, but by applying the new methods and drugs, it can be treated really well. Modern combination therapies have reported up to $60-80 \%$ of patients reaching a complete response [20].

Economic aspects of multiple myeloma. Since the financing of treatment of oncological patients requires a rather higher number of financial resources, it is important for payers to identify the real costs associated with the disease. Within the health economics literature, the costs associated with interventions are usually divided into two basic types, direct and indirect. Generally, the direct costs are the opportunity costs of formal health-care goods and services such as hospitals, physicians, drugs, and so on [21]. The imputed value of foregone labor products when patients' labor services become inefficient or are withdrawn from production on account of morbidity or premature mortality is widely regarded as an indirect cost [21]. Usually, the key stakeholders consider the direct medical costs only [22-24], but for a full picture, we also need to consider the indirect costs $[25,26]$ paid by payers that create an inevitable part of total costs evaluation.

Many studies focused on indirect costs of various cancers confirmed that the resources and costs incurred by cancer patients and caregivers outside the healthcare system are substantial [27-29]. Based on the results of an international trial of myeloma patients, Robinson et al. [30] call for further investigation of a hypothesis that durable overall and complete responses will lower work absenteeism and diseasedriven rates of early retirement, disability, and unemployment. From a broader perspective of hematological malignancies, Wang et al. [31] provided interesting results by analyzing survival gains in chronic myeloid leukemia (CML) achieved by treatment with targeted therapy, tyrosine kinase inhibitors (TKI). They estimated that since its introduction in 2001, the tyrosine kinase inhibitors drug class in CML therapy has created more than $\$ 143$ billion in social value. The most important role of the social security system is to alleviate the impact of productivity loss on the standard of life. The social security system in Slovakia has three basic forms - social insurance, social assistance, and social support. The entitlement to benefit from a particular form depends on many different circumstances and factors such as the period of payment contributions to the social security system, the number of payments, family income, or the individual capacity to overcome disability [32].

The development of the economic burden is partly a reflection of the development in cancer incidence and cancer mortality [33]. One of the ways to measure societal costs of cancer is to estimate the cost of lost productivity due to cancer-related premature mortality in a cost-of-illness study. Although cancer-related morbidity also causes other types of productivity losses, most studies suggest that mortality costs comprise the largest proportion of productivity costs [34-38]. Several studies have assessed labor productivity losses due to mortality and morbidity for $\mathrm{MM}$ and other malignancies [39-43]. Some of them have focused on specific types of cancer such as pancreatic or breast cancer [31, 44, 45]. However, few studies have reported information about labor productivity losses due to blood cancer, one study was published two decades ago in Sweden evaluating myeloid leukemia [46], two articles concerning chronic lymphocytic leukemia and lymphoma were published in Germany [47, 48], and leukemia and lymphoma were found to be amongst ten of the costliest cancers in terms of lost productivity due to premature cancer-related mortality $[42,49]$.

Based on our research and findings, there are currently no local published data that would evaluate losses in labor productivity due to death or premature death in working-age patients with multiple myeloma as well as all costs associated with this disease from the perspective of the payer. A key purpose of our research was to provide detailed and most accurate information related to the spectrum of economic aspects of blood cancer from the perspective of direct and indirect costs.

\section{Methods}

We performed the retrospective economic analysis focused on direct medical and non-medical costs and indirect costs from the state payers perspective with the partnership of the key local stakeholders and payers including the Ministry of Health of the Slovak Republic (MoH), the Ministry of Labor, 
Social Affairs and Family of the Slovak Republic (MoL), the state-owned General Insurance Company (Všeobecná zdravotná poistovňa, VšZP) that holds $62 \%$ market share at the health insurance market share in Slovakia [50], National Health Information Centre (NCZI), and Social Insurance Agency in Slovakia (SoP). We also cooperated with specialists on MM from National Cancer Institute (NOU) in Bratislava. According to Morris et al. [51], the approaches to costing basically falls into two broad types: macro - or "top-down" costing, and micro or "bottom-up" costing. These are distinguished largely on the basis of the level of disaggregation at which individual resources are measured and valued as separate components. For the purpose of our analysis, we used "bottom-up" approach that helped us identify, quantify, and value the resources in a disaggregated way, so that each element of costs was estimated individually and they were summed up at the end, similarly to our first costing project with the same indication $[24,25]$. Slovak Republic has no validated disaggregated national database that would contain valid and verified epidemiological data on MM, details of treatments or mortality rates of malignant hematological diseases, not since 2008. The most reliable MM patient data currently available are in the RMG Registry existing in the Czech Republic that includes data from several Slovak centers [52]. Due to the missing national cancer registry or national MM registry, we used the last available RMG registry data for Slovakia (4 centers out of 8 centers in SK: Banská Bystrica, Bratislava, Košice, Martin) [52]. Centers reported data on MM till 2017 and data represents major geographical parts of Slovakia. We searched for the total adult population (over 18 years of age) till retirement age (62 years of age) with the diagnosis of MM. Mortality data were obtained from the National Health Information Center [12] and were validated by the Institute of Health Policies at the Ministry of Health of Slovak Republic [53]. Data were approved only for the purpose of this analysis and correctness can be verified directly with the IZP.

The costs were calculated for a model patient with MM in productive age from the diagnosis till death timeframe based on the agreement with key decision-makers VšZP and $\mathrm{MoH}$. The human capital approach was agreed, as well. According to the WHO International Classification of Diseases, the patients with MM fall into the diagnosis group C90.00 and C90.01 [54, 55]. Data from the RMG multiple myeloma registry in Slovak and Czech Republic showed patients with MM in productive age created in 2017 up to $56.2 \%$ from a total population of MM patients in the Slovak Republic and the average age of patients with MM in productive age was 53 years old [52]. Since we did not find any current local study about MM with the focus on treatment length and treatment-free intervals, we took into consideration the publication by Yong et al. [56] and their data on the proportion of patients who had received each line from the cross-sectional review and the data on duration of treatment and treatmentfree intervals. It was the retrospective review that considered the treatment durations and outcomes, and symptom burden across the treatment pathway in Belgium, France, Germany, Italy, Spain, Switzerland, and the UK [56]. Direct medical costs consisted of medical diagnostics, outpatient consultations, hospitalization, drug acquisition, drug administration, and treatment incurred at clinics and specialized cancer departments in the hospitals. From the health care system perspective, direct medical costs for diagnosis, pre-operative assessments, treatment, inpatient hospitalization, and outpatient specialist clinic follow-up are the most relevant. Another set of cost data are indirect costs such as productivity loss due to morbidity and mortality, invalidity costs, and social security costs for patients. Disability pension costs that were part of the costs associated with invalidity due to MM can be considered as transferred payments and not being real economic costs, but from the perspective of our study where the decision-makers need to consider full costs of labor and capital, we decided to include it into our analysis. Costs data were provided by the General Insurance Company, based on our request for preparing data for the analysis. According to current Slovak law, the General Insurance Company is not authorized to provide cost data externally, except in a specific situation to the National Health Information Centre for specific purposes outside of the scope of our analysis. However, the General Insurance Company as well as $\mathrm{MoH}$ verified all our results and calculations and are available for further comments or requests connected with this analysis.

Indirect costs associated with MM included the costs of lost work due to absenteeism or impaired productivity at work, disability, and mainly the productivity loss due to premature death due to MM. Given the complexity of the social security system, there is no legal assurance guaranteeing benefits explicitly on the basis of a diagnosis of MM. Therefore, it was not possible to draw a connection between the legal existence of the particular benefit and the amount of support received by a patient. Hence, it was impossible to calculate indirect costs associated with MM solely by multiplying the estimated number of MM patients in Slovakia with the total sum of benefits they may be entitled to receive according to law. For the purpose of the analysis, we requested data on social security benefits expended on patients with MM from the administrative offices responsible for assessing claims on particular forms of social support. Social Insurance Agency provided us with general data about the number of people with myeloma receiving a disability pension. State social assistance in severe disability falls in the competence of Offices of Labor, Social Affairs and Family. The Central Office of Labor, Social Affairs and Family provided us with data on the number of people holding the card of a person with a severe disability and with the data on the number and type of cash benefits received by myeloma patients. We have decided not to include these in the analysis, as with the effect of 1 July 2018 , there was a major amendment to the law that changed the conditions for their assessment [57]. The data collected before the legislation amendment would distort the true 
picture of costs expended on people with myeloma under the system of assistance in severe disability. According to the Slovak Social Insurance Act [32], a person who is incapable of work may receive a sickness benefit for the period of one year (52 weeks). Only long-term medical conditions may be recognized as a disability for the purpose of a disability pension. The long-term is legally defined as a condition, which lasts or, according to the current medical knowledge, shall last at least one year. For this reason, a disability pension is usually granted only after one year of incapacity for work. According to the Slovak legislation [32], disability is associated with a long-term reduction of the capacity to perform a gainful activity by more than $40 \%$ compared to a healthy person. In case of partial disability (reduction by $41-70 \%$ ), the pension amount depends on the number of years of the insurance in the Social Insurance Agency, on the average personal wage point, and on the current pension value valid on the day the entitlement to pension arose, as well as on the percentage of reduction of the capacity to perform gainful activity. In the case of full disability, the specific percentage of the reduction does not affect the pension amount. The specific reduction of the capacity to perform the gainful activity due to particular illnesses is set in the Social Insurance Act [32]. MM is associated with a reduction between $10 \%$ and $80 \%$ depending on the MM stage, specific complications, and impact on the overall performance of the body. A patient in remission, without any complication, cannot be assessed as disabled. A partial disability pension may be granted to a patient with moderate clinical and laboratory symptoms and reduced overall performance of the organism e.g., due to fatigue. A full disability pension shall be attributed to a patient experiencing typical serious complications such as severe anemia, pain, bone fractures, renal failure. After a certain period of time (usually two years), a pensioner may be summoned to a medical assessment that may lead to a change in the percentage, hence the disability pension may change or even be withdrawn. Considering the average 4.5-year survival rate in MM for the model patient, the calculation of the indirect costs expended from the social security system was based on a model myeloma patient with the average age of 53 receiving sickness benefits for a period of 12 months and disability pension for a period of 48 months.

Lost productivity costs due to premature death due to MM was calculated in Slovakia for the first time. To have comparable results with other international studies, the methodological approach was similar to the one used in [39]. Multiple myeloma deaths were calculated in terms of years of potential life lost (YPLL) and years of potential productive life lost (YPPLL). YPLL was calculated using the methodological approach by Gardner and Sanborn [58]. The YPLL involves estimating the average time a person would have lived had he or she not died prematurely. YPLL is used to help quantify social and economic loss due to premature death and incorporates age at death, and its calculation mathematically weights the total deaths by applying values to death at each age. The range of early mortality was considered in several age groups of patients with MM, under 46 years old, 46-50 years old, 51-55 years old, 56-60 years old, and last group was 61-65 years old, where the age of retirement was included (62 years of age). Additionally, the YPPLL were calculated by estimating the number of total deaths during working age (18 and 62 years of age). The legal age of retirement in the Slovak Republic is currently 62 years of age. For these calculations, we did not use any discount rate. To calculate the costs of premature mortality due to MM, we applied the human capital (HC) approach. The human-capital method takes the patient's perspective and counts any hour not worked as an hour lost, stress the negative effects on the health of an individual that might cause undesirable effects on their total productivity [59]. In the case of the productive member of society who leaves the labor market due to premature mortality, the potential labor productivity towards the end of their working life will have been lost by society [60]. As a reasonable estimation of the labor productivity, we used the average national wage from the official prediction materials of the Ministry of Finance, $€ 1,009$ [61]. We used the incidence approach. We calculated the number of deaths of working-age individuals from the available MM registry and from the data provided by the National Health Information Centre and validated by $\mathrm{MoH}[52,62]$. The maximum age limit for the workers to remain in the labor market was set at 62 years. We calculated the present and future flow of productivity loss due to premature death from MM after we considered the age at the time of death and expected gross lifetime income. Furthermore, the expected income, the employment rate, the real labor productivity, the inflation rates, and the average salary growth index were applied to calculation controlled by age and gender up to the predetermined limit of 65 years. The employment data was obtained from the latest official report of the Ministry of Finance [61]. The employment rate is defined as the percentage of the population that is employed in relation to the total population of working age. The costs were used for the year 2018 . Our analysis considered the current and expected annual growth rate of labor productivity in Slovakia from 2005 to 2021 , which was $1.03 \%$ [61] and the $2.13 \%$ as the annual discount rate in line with the recent methodological suggestions in economic evaluations [39]. The average survival rate for patients was considered at the level of 3.75 years [63-67].

\section{Results}

According to the data sets we have received from the Ministry of Health, General Insurance Company, Ministry of Labor, National Health Information Centre, and Social Insurance Agency and according to the treatment management based on currently valid multiple myeloma, Slovak and Czech guidelines additionally consulted with specialists at the field multiple myeloma [68], we have identified and summarized all available direct and indirect costs in Table 1. 
Table 1. Costs for the model patient with MM in Slovakia from diagnosis till death. (Sources: VšZP, MoH, NCZI).

\begin{tabular}{l} 
Cost group \\
$\begin{array}{l}\text { Total } \\
\text { Diagnostics costs (including out-patient diagnostic tests, radio-diagnostics, laboratory diagnostics, CT, MRI, X-rays, etc.) } \\
\text { Special therapeutic/medical procedures (including bone marrow transplant, radio-high-voltage therapy, etc.) }\end{array}$ \\
Hospitalization (stay at hospital bed due to MM more than 48 hours) \\
Pharmaco-therapy costs (out-patient treatment, administration, and drug preparation costs included) \\
Sickness Benefits/Invalidity/Long Term Disability \\
Costs of productivity loss due to premature death from MM (in productive age, based on 2017 deaths, cost for the Slovak Republic) \\
Total costs \\
\hline 19,229
\end{tabular}

Table 2. Unit costs used in the analysis.

\begin{tabular}{|c|c|c|}
\hline Unit & Costs $(€)$ & Specifications \\
\hline $\begin{array}{l}\text { VTD (bortezomib } 1.3 \mathrm{mg} / \mathrm{m}^{2} \text {, thalidomide } 100 \mathrm{mg} \text {, dexametha- } \\
\text { sone } 40 \mathrm{mg} \text { ) }\end{array}$ & 13,511 & $\begin{array}{l}\text { number of cycles } 4 \text {, fee for drugs dilution and administration } € 842.42 \text { is } \\
\text { included }\end{array}$ \\
\hline Cyclophosphamide (dosage $2.5 \mathrm{~g} / \mathrm{m}^{2}$ ) & 351 & fee for drugs dilution and administration $€ 233.69$ is included \\
\hline Myeloablation (melphalan, dosage 200 mg/m²) & 1,434 & fee for drugs dilution and administration $€ 81.92$ is included \\
\hline 1st transplantation & 15,727 & \\
\hline Myeloablation (melphalan, dosage 140 mg/m²) & 1,178 & fee for drugs dilution and administration $€ 81.92$ is included \\
\hline 2nd transplantation & 15,727 & \\
\hline RD (lenalidomid $25 \mathrm{mg}$ at the beginning, dexamethasone $40 \mathrm{mg}$ ) & 86,371 & $\begin{array}{l}\text { number of cycles } 20 \text {, fee for drugs dilution and administration } € 3,035.28 \\
\text { is included }\end{array}$ \\
\hline $\begin{array}{l}\text { VCD (cyclophosphamide } 900 \mathrm{mg} / \mathrm{m}^{2} \text {, bortezomib } 1,3 \mathrm{mg} / \mathrm{m}^{2} \text {, } \\
\text { dexamethasone } 40 \mathrm{mg} \text { ) }\end{array}$ & 15,313 & $\begin{array}{l}\text { number of cycles } 6 \text {, fee for drugs dilution and administration } € 983.05 \text { is } \\
\text { included }\end{array}$ \\
\hline $\begin{array}{l}\text { VMP (bortezomib } 1.3 \mathrm{mg} / \mathrm{m}^{2} \text {, melphalan } 9 \mathrm{~g} / \mathrm{m}^{2} \text {, prednisone } \\
60 \mathrm{mg} / \mathrm{m}^{2} \text { ) }\end{array}$ & 12,244 & $\begin{array}{l}\text { number of cycles } 6 \text {, fee for drugs dilution and administration } € 947.72 \text { is } \\
\text { included }\end{array}$ \\
\hline $\begin{array}{l}\text { CAD senior (cyclophosphamide } 50 \mathrm{mg} \text {, doxorubicin } 9 \mathrm{mg} / \mathrm{m}^{2} \text {, } \\
\text { dexamethasone } 20 \mathrm{mg} / \text { day) }\end{array}$ & 19,276 & $\begin{array}{l}\text { number of cycles } 4 \text {, fee for drugs dilution and administration } € 9,175.15 \\
\text { is included }\end{array}$ \\
\hline Radiotherapy & 6,654 & 2 therapies including hospitalization \\
\hline Hospitalization & 40,581 & 4 hospitalizations due to transplantations are included \\
\hline Zoledronate (4 mg) & 1,431 & \\
\hline Filgrastim $(5 \mu \mathrm{g} / \mathrm{kg} /$ day $)$ & 2,019 & \\
\hline Hematological tests & 3,495 & \\
\hline Blood chemistry tests & 11,448 & \\
\hline Serology & 78 & \\
\hline Special tests (EKG, X-rays, etc.) & 1,199 & \\
\hline Hospital care (at least 48 hours) & 3,865 & \\
\hline
\end{tabular}

Sickness benefits. In general, the amount of the sickness benefit is $25 \%$ of the gross income of the insured person for the first three days of the incapacity for work and $55 \%$ of the gross income starting from the fourth day of the incapacity for work [32]. Unfortunately, we weren't able to obtain information on the average amount of sickness benefits expended precisely on persons certified as temporarily incapable to work due to MM. According to the publicly available data, the average monthly sickness benefits paid by the Social Insurance Agency in 2017 were in an amount of €252 [69]. Our model patient with MM receiving sickness benefits for a period of one year would cost the insurance system $€ 3,024$.

Disability. According to the data provided by the Social Insurance Agency, in 2017, 30 people with myeloma were receiving a disability pension, among which 4 were partial and 26 fully disabled. We have not been provided with the data on the specific amount of these pensions. Based on the publicly available data the average partial disability pension in 2017 amounted to $€ 201.89$ and a full pension to $€ 359.18$ [70]. On the basis of these data, we were able to establish that the Social Insurance Agency paid $€ 20,690.72$ due to a partial disability pension in the year 2017 and $€ 112,064.16$ due to a full disability pension, a total of $€ 121,754.88$, representing $€ 338.21$ for an average patient with myeloma per month. Our model myeloma patient receiving disability pension for the period up to 72 months would cost the Social Insurance Agency $€ 20,292.60$. We did not take into calculation the annual valorization of disability pensions depending on the inflation rate in the given calendar year. Overall costs for the model patient in productive age with $\mathrm{MM}$, considering the age categories and different length of sickness benefit and disability, was $€ 19,985$. The Slovak pension system does not permit to receive a disability pension from a source other than the Social Insurance Company $[32,71]$. 
Productivity loss. According to official data, the life expectancy in the Slovak Republic is 77.3 years of age [72]. The overall average age of patients with MM was 63.4 years of age [52]. The average age of patients in hospital care with MM under the official retirement age was 50 years of age [53] and in primary care 52.5 years of age [53]. The percentage of all patients with MM under the retirement age was $48.73 \%$ $[53,62]$ and the average age of a patient with MM in working age (under the retirement age) was 52.6 years of age $[53,62]$. When distributing the deaths by age for all genders, we have found that most of the deaths occurred in the 56-60 age group (38.95\%) followed by the 51-55 age group (33.15\%). For the age group of patients between 46-50, the death rate was lower compare to the group of patients under 46 years ( $13.54 \%$ vs. $14.36 \%$, respectively). The YPLL and YPPLL for patients with MM in Slovakia were calculated as 10.16 and 7.75 respectively. Based on all data validated with the Ministry of Health, Institute of Health Policies, the total labor productivity loss due to premature death in a patient with MM in working age was in 2018 at the level of $€ 5,451,499$. The average potential productivity loss per 1 patient with MM was $€ 127,611$, taking into account also the lost statutory deductions paid by employee and employer to state according to current law (Table 3). Furthermore, $69.20 \%$ of productivity losses were generated by people who die till the age of 50 (Table 4).

\section{Discussion}

For our analysis, we took into consideration and as the source of our inspiration available publications at the field of costs associated with cancer or MM. Luengo-Fernandez et al. [43] published a population-based cost analysis that evaluated the cost of all cancers and also those associated with breast, colorectal, lung, and prostate cancers. They focused on direct and also indirect costs. The study estimated total cancer cost at the level of $€ 126$ billion in 2009 (European Union, EU), with health care accounting for $40 \%$ (€51.0 billion) from total costs. Our current analysis showed that direct (health care) costs were responsible for at least $64 \%$ $(€ 261,475)$ from total costs, which is much more than in our previous analysis where direct costs created $34 \%(€ 69,633)$ [24]. The health-care costs of cancer varied substantially across the EU from $€ 16 /$ person in Bulgaria to $€ 184 /$ person in Luxembourg. Total productivity loss because of premature death due to cancer in the EU was $€ 42.6$ billion and productivity loss due to sick leaves was $€ 9.43$ billion. Costs associated with the family taking care of the patient with cancer were $€ 23.2$ billion [43]. The study also showed that similarly to our analysis where we took into consideration the first 12 months' treatment from the diagnosis, the indirect costs associated with cancer were the biggest part of total costs (66\%; €133,534.60 for MM in Slovakia), but taken into consideration the whole treatment phases from diagnosis till death, the indirect costs were $36 \%(€ 147,596)$ from total costs [24]. The reasons for this were the prolonged treatment period with expensive technology, more hospitalizations, and hundreds of laboratory tests done during the treatment period. According to Fonseca et al. [73], MM treatmentrelated drug costs accounted for $10.6 \%$ of total healthcare costs among MM patients in 2000 , increasing to $20.3 \%$ in 2007 and $28.5 \%$ in 2014 . Results from our analysis showed that for the model patient with MM, drug treatment costs accounted approximately for $38 \%(€ 155,645)$ of total costs. Additionally, the study from Burns et al. [74] focused on the area of malignant blood cancer (where MM belongs) was aimed to assess the economic burden of malignant blood disorders across the 28 countries in the EU, Iceland, Norway, and Switzerland. The study focused on direct and indirect costs and for countries in the EU, malignant blood disorders were compared with the economic burden of overall cancer. Malignant blood disorders cost the 31 European countries $€ 12$ billion in 2012 . Health-care cost $€ 7.3$ billion (62\% of total costs), productivity losses cost €3.6 billion (30\%), and informal care cost $€ 1$ billion (8\%). For the EU countries, malignant blood disorders cost $€ 6.8$ billion (12\%)

Table 3. The productivity loss due to premature death in patients with MM in working age in Slovak Republic (year 2018).

\begin{tabular}{lccc}
\hline Age category & $\begin{array}{c}\text { Number of patients after } \\
\text { employment rate adjustment }\end{array}$ & $\begin{array}{c}\text { Productivity loss-all patients } \\
\text { (total, in } € \text { ) }\end{array}$ & $\begin{array}{c}\text { Productivity loss per 1 patient } \\
\text { (total, in } € \text { ) }\end{array}$ \\
\hline$<46$ & 9.7 & $2,378,811$ & 331,386 \\
$46-50$ & 9.1 & $1,393,630$ & 206,029 \\
$51-55$ & 22.4 & $1,599,600$ & 96,562 \\
$56-60$ & 26.3 & 79,457 & 4,082 \\
\hline
\end{tabular}

Table 4. Productivity loss according to the age group defined by RMG Registry (RMG, 2018).

\begin{tabular}{lccc}
\hline Age category & $\begin{array}{c}\text { Number of patients after } \\
\text { employment rate adjustment }\end{array}$ & $\begin{array}{c}\text { Productivity loss-all patients } \\
\text { (total, in } € \text { ) }\end{array}$ & Ratio (\%) \\
\hline$<46$ & 9.7 & $2,378,811$ & 43.64 \\
$46-50$ & 9.1 & $1,393,630$ & 25.56 \\
$51-55$ & 22.4 & $1,599,600$ & 29.34 \\
$56-60$ & 26.3 & 79,457 & 1.46 \\
\hline
\end{tabular}


of the total health-care expenditure on cancer ( $€ 57$ billion) [74]. The study showed that in countries where patients with blood cancer have better access to innovations, treatment costs are lower, which positively influences also the overall healthcare costs. In line with our results, Burns et al. [74] confirmed that patients with blood cancer facing significant work productivity loss. We have found that the median time on sick leave in patients with MM was during years 2016 and 20178 months [69]. Europe, in 2012, has lost only on sick leaves due to blood cancer more than $€ 2$ billion, which is approximately $0.6 \%$ GDP per year [43].

It is worth mentioning that the reduction in the capacity to perform the gainful activity within the statutory scope is not the only condition for entitlement for a disability pension. A person must reach a sufficient number of pension insurance years depending on age and must not reach the retirement age. Due to the fact that the MM is typically diagnosed between the ages of 65-74 years, many patients do not currently fulfill this condition for granting a disability pension [73]. Nevertheless, the number of myeloma patients below the retirement age may be expected to increase. The official retirement age of 62 years shall increase on yearly basis according to the median life expectancy, with the retirement age of 62 years and 139 days in 2018 to approximately 64 and six months in 2030, assuming that there will be no major change of legislation and unexpected twists in the median life expectancy of the population $[32,75,76]$. Considering the lack of up-to-date official epidemiological data due to the long-term dysfunction of the Slovak Oncology Registry, the number of myeloma patients below the country's official retirement age may be much broader than expected according to the data inferred from the epidemiology of other countries [62]. Legal regulation could be considered a reason why, in contrast to other studies, early retirement is not included in the scope of indirect costs associated with MM [77]. Given the fact that taking early retirement leads to a lower old-age pension, it is in general more profitable to receive a disability pension up until reaching the official retirement age. The recipient of a disability pension is allowed to perform any gainful activity without legal limitation. On the one hand, such an arrangement is perfectly understandable. The pensioner has been contributing to the social insurance system with the expectation of provision of the benefit (disability pension) when an insured event (disability) occurs and shall not be limited in productivity in case of improvement of the medical condition, whether temporary or permanent. It is also true, that the above discussed average disability pension could not be considered an adequate substitution of an average salary of $€ 954$ [78]. On the other hand, such regulation implies that a person fulfilling the legal criteria of disability is still able to work which can lead to doubts about their accuracy. More importantly, the regulation narrows the scope for the argument that the reimbursement of innovative treatment will allow the society to save money expended on disability pensions. Given the rising costs of innovative treatment, tough societal discussion on this issue could be expected in the coming years.

Leave of absence due to incapability for work is not the only way how employees handle the necessity for absence associated with their medical condition. According to the Slovak Labor Code [79], an employer shall provide an employee with paid leave for the purpose of medical examination in a maximum of seven days a year. In case an employee needs additional leave for this purpose, an employer is obliged to permit it as unpaid. With regard to the indirect costs of MM arising from absence at work, it is also worth mentioning the lost days of productivity among careers. The employer is obliged to provide the employee with paid leave to accompany a family member to the medical facility for a maximum of seven days a year. The patient may be accompanied by any family member, so it is entirely possible that all of the patient's relatives will take their turn within the statutory scope. A sickness insured relative may also apply for nursing care benefit in the amount of $55 \%$ of the gross wage of the insured person. The benefit is paid for a maximum period of 10 days. Indirect costs arising from short-term absence in employment were not included in the analysis as no data are available on the specific medical reason for the absence from work. Similarly, without knowing the reasons for the absence, a conclusive statement that the workdays taken by patients' families were used exclusively for caring for the patients cannot be made. Also, it cannot be ruled out that patients and their family members used paid vacation to cover their need for health-related absence from work. Furthermore, 69.20\% of productivity losses were generated by people who die till the age of 50 (Table 4).

From the perspective of the costs associated with the productivity loss due to premature death from MM, we found the publication by Hanly et al. [49] where lost productivity due to the premature death of cancer was available and calculated also for Slovakia at the level of $€ 128,179$. A similar result could be found within the study by Ortega-Ortega et al. [39] were total productivity loss per person in Spanish patients with hematological malignancies such as the MM, myelodysplastic syndrome, and other except acute leukemia and lymphoma was $€ 132,093$. In the study by Pearce et al. [80] the productivity losses per cancer death in Ireland between 2011 and 2030 , testis $(€ 364,000 /$ death), cervix (€155,000/ death), and brain cancer $(€ 136,000 /$ death) were much higher because they affect the full spectrum of working-age individuals. Costs associated with the productivity loss due to premature death from MM was calculated and verified with the Institute for Health Policy at the Ministry of Health and Ministry of Finance of the Slovak Republic and was similar to previously published and mentioned data $(€ 127,611)$, but this is for the year 2017 where we already knew how many patients died due to MM. A detailed report concerning the calculation will be submitted as a separate full-paper.

Our study has several limitations. The treatment length, treatment-free intervals, and overall epidemiological data 
were adjusted to the local situation from the sources outside of our jurisdiction. Where needed, local experts have been consulted. Since all cost data used for our analysis are not publicly available, there is limited opportunity for anyone to receive up-to-date cost data from any registry or publicly available portal in Slovakia. Direct costs were extracted directly from the state health insurance databases and were verified by the insurance once we made all the calculations. Concerning the indirect costs, further C90.0 classification was not available; however, these data were provided by the Social Security Agency and Ministry of Labor. Additionally, once we were able to obtain data from official state or private institutions, they were not able to specify if direct or indirect costs data are just for one diagnosis (C90.0) or there are cumulated costs for all diagnoses that may patients with MM suffered from. The only data source for disability and invalidity costs were agencies of the social care system. Some of the data lacked specificity needed for concrete calculations, e.g., for the calculation of average sickness benefits of a patient with myeloma. However, given the unsatisfactory situation with data management in the Slovak Republic, the mere fact the agencies have provided us with data in scope was highly unusual in Slovak circumstances and can be considered a major achievement. Another limitation of the study is a result of legislation constraints preventing us from including data on the compensation of severe disability to calculation. Even if the severe disability allowances could have been included, the real indirect societal burden of myeloma is much more complex. Apart from benefits and pensions from the social insurance system and benefits paid under the severe disability compensation systems, there is a system of social services managed and operated by municipalities, which also contributes to the total costs of care for a myeloma patient in Slovakia.

Additional analysis to estimate the labor productivity losses by using the friction cost (FC) method was not used. For this approach, we did not have any reliable source that would describe the "friction period" for the patient with MM that leaves the job because of illness or premature mortality. Generally, this does not cause a large loss in productivity for the society considering the short period of replacement of one worker for another. The short average survival was calculated from official international statistics but without exact local data. This result takes into consideration consultations with specialists on MM, problematic access to innovations, and regulatory barriers to follow-up healthcare.

In conclusion, the cost of treatment of the patients with $\mathrm{MM}$ is a complex issue consisting of variety of partial expenses, which cannot be omitted when calculating the actual total costs. Patients with MM are affected by this disease not only physically, but also psychically and it is often hard for them to integrate into everyday life. Indirect data are still not the regular part of the evaluation of existing or new technologies coming to the healthcare system and data, which we were able to obtain directly from state institutions, are not publicly available. We should direct the next steps towards authentication and specification of the data, e.g., by means of questionnaires send to myeloma patients, and focus on following up the real impact of legislation amendments and collecting the myeloma patients' data within the system of social services. Additionally, we should continue in dialogue with key stakeholders that all costs are available and taken under consideration. While doing so, we need to link the specific stages of myeloma requiring specific treatment and to the indirect costs whenever it's possible. In our opinion, this is the only way to develop evidence-based argumentation in the very needed public discussion about the real value of innovation. Patients with MM in their productive age face significant losses in productivity, so does the state. We prepared the first total costs base that can be used for the evaluation of current and new technologies entering the MM field.

\section{References}

[1] COWAN AJ, ALLEN C, BARAC A, BASALEEM H, BENSENOR I et al. Global Burden of Multiple Myeloma: A Systematic Analysis for the Global Burden of Disease Study 2016. JAMA Oncol 2018; 4: 1221-1227. https://doi.org/10.1001/ jamaoncol.2018.2128

[2] KAZANDJIAN D. Multiple myeloma epidemiology and survival: A unique malignancy. Semin Oncol 2016; 43: 676-681. https://doi.org/10.1053/j.seminoncol.2016.11.004

[3] PALUMBO A, ANDERSON K. Multiple myeloma. N Engl J Med 2011; 364: 1046-1060. https://doi.org/10.1056/NEJMra1011442

[4] TERAS LR, DESANTIS CE, CERHAN JR, MORTON LM, JEMAL A et al. US lymphoid malignancy statistics by World Health Organization subtypes. CA Cancer J Clin 2016; 66: 443-459. https://doi.org/10.3322/caac.21357

[5] SIEGEL RL, MILLER KD, JEMAL A. Cancer statistics, 2016. CA Cancer J Clin 2016; 66: 7-30. https://doi.org/10.3322/ caac. 21332

[6] CID RUZAFA J, MERINOPOULOU E, BAGGALEY RF, LEIGHTON P, WERTHER W et al. Patient population with multiple myeloma and transitions across different lines of therapy in the USA: an epidemiologic model. Pharmacoepidemiol Drug Saf 2016; 25: 871-879. https://doi.org/10.1002/ pds.3927

[7] PHEKOO KJ, SCHEY SA, RICHARDS MA, BEVAN DH, BELL $S$ et al. A population study to define the incidence and survival of multiple myeloma in a National Health Service Region in UK. Br J Haematol 2004; 127: 299-304. https://doi. org/10.1111/j.1365-2141.2004.05207.x

[8] SANT M, ALLEMANI C, TEREANU C, DE ANGELIS R, CAPOCACCIA R et al. Incidence of hematologic malignancies in Europe by morphologic subtype: results of the HAEMACARE project. Blood 2010; 116: 3724-3734. https://doi. org/10.1182/blood-2010-05-282632

[9] KYLE RA, GERTZ MA, WITZIG TE, et al. Review of 1027 patients with newly diagnosed multiple myeloma. Mayo Clin Proc 2003; 78: 21-33. https://doi.org/10.4065/78.1.21 
[10] BLADE J, KYLE RA, GREIPP PR. Multiple myeloma in patients younger than 30 years. Report of 10 cases and review of the literature. Arch Intern Med 1996; 156: 1463-1468. https://doi.org/10.1001/archinte.1996.00440120125014

[11] HOWLADER N, NOONE AM, KRAPCHO M, MILLER D, BISHOP K et al., editors. SEER Cancer Statistics Review, 1975-2013. Bethesda, MD: National Cancer Institute, 2016. https://seer.cancer.gov/archive/csr/1975_2013/results_ merged/sect_18_myeloma.pdf [As accessed on November 03, 2020]

[12] [NATIONAL ONCOLOGICAL REGISTER OF THE SLOVAK REPUBLIC (NCZI)-PRESENTATION OF OUTPUTS.] [Estimation of the incidence of malignant tumors (according to NCZI); National Center for Health Information, 2020.] https://iszi.nczisk.sk/nor.sr/incidencia/odhad/sumarny-prehlad?filter $=\{\% 22$ ukazovatel $\% 2$ 2:\%22abs\%22,\%22pohlavie\%22:[\%22M\%22,\%22Z\%22] ,\%22rok-od\%22:2020,\%22rok-do\%22:2030,\%22diagno za\%22:[\%2230\%22]\} [As accessed on November 03, 2020]

[13] SAKALOVÁ A, ŠTEFÁNIKOVÁ Z, HRIANKA M, MASÁROVÁ K, MISTRÍK M, et al. (Eds.) [Current treatment of multiple myeloma and its perspectives.] A-medi management, s.r.o., Bratislava 2016.

[14] VORLÍČEK J, ADAM Z. (Eds.) [Multiple myeloma-treatment guidelines for general practitioners.] [Czech Medical Society of Jan Evangelista Purkyně], Praha 2002.

[15] HLAVATÝ T, LIPTÁKOVÁ A, ŠPÍROVÁ R, ÉLEŠOVÁ M, SLEZÁKOVÁ Z et al. (Eds.) [Report on the state of healthcare in Slovakia.] [Ministry of Health of the Slovak Republic], Bratislava 2011, p. 240. ISBN 0978-80-969507-9-9. https://www.health.gov.sk/Zdroje?/dokumenty/Sprava-ostave-zdravotnictva-na-Slovensku.pdf

[16] LYNCH HT, SANGER WG, PIRRUCCELLO S, QUINNLAQUER B, WEISENBURGER DD. Familial Multiple Myeloma: a Family Study and Review of the Literature. J Natl Cancer Inst 2001; 93: 1479-1483. https://doi.org/10.1093/ jnci/93.19.1479

[17] KUMAR SK, RAJKUMAR V, KYLE RA, VAN DUIN M, SONNEVELD P et al. Multiple myeloma. Nat Rev Dis Primers 2017; 3: 17046. https://doi.org/10.1038/nrdp.2017.46

[18] JUNGOVA A, VOKURKA S, SCHUTZOVA M, STEINEROVA K, MOHAMMADOVA L et al. Comparison of autologous hematopoietic cell transplantation performed in tandem and in disease relapse in multiple myeloma patients. Neoplasma 2018; 65: 952-957. https://doi.org/10.4149/ neo_2018_170511N346

[19] HÁJEK R, JARKOVSKY J, MAISNAR V, POUR L, ŠPIČKA I et al. Real-world Outcomes of Multiple Myeloma: Retrospective Analysis of the Czech Registry of Monoclonal Gammopathies. Clin Lymphoma Myeloma Leuk 2018; 18: e219e240. https://doi.org/10.1016/j.clml.2018.04.003.

[20] LANDGREN O, RAJKUMAR SV. New Developments in Diagnosis, Prognosis, and Assessment of Response in Multiple Myeloma. Clin Cancer Res 2016; 22: 5428-5433. https://doi. org/10.1158/1078-0432.CCR-16-0866

[21] ERNST R. Indirect Costs and Cost-Effectiveness Analysis. Value Health 2006; 9: 253-261. https://doi.org/10.1111/ j.1524-4733.2006.00114.x
[22] LEE JK, KIM DW, KEAM B, KIM TM, LEE SH et al. The Impact of Molecularly Targeted Treatment on Direct Medical Costs in Patients with Advanced Non-small Cell Lung Cancer. Cancer Res Treat 2015; 47: 182-188. https://doi. org/10.4143/crt.2013.227

[23] BABELA R, RAFAYOVA M, HURNA J. Total Costs Distribution for Multiple Myeloma in Single Upper Middle Income Country: Is Cost Data Distribution Comparable with High Income Countries? Value Health 2018; 21: S28. https:// doi.org/10.1016/j.jval.2018.04.178

[24] BABELA R, RAFAYOVA, M, HURNA J. Direct Costs Associated with Multiple Myeloma Model Patient in 2017 From Single EU Jurisdiction. Value Health 2018; 21: S27-S28 https://doi.org/10.1016/j.jval.2018.04.175

[25] BABELA R, RAFAYOVA M, HURNA J. What are the Real Indirect Costs Associated with Multiple Myeloma: Model Patient Analysis From Slovak Republic. Value Health 2018; 21: S25. https://doi.org/10.1016/j.jval.2018.04.158

[26] SANTERRE RE, NEUN SP. (Eds.) Health Economics: Theories, Insights, and Industry Studies, $5^{\text {th }}$ Edition. Cengage Learning, Boston 2009, p.624. ISBN-13: 978-0324789072

[27] JAYADEVAPPA R, SCHWARTZ S, CHHATRE S, GALLO J, WEIN AJ et al. The Burden of Out-of-Pocket and Indirect Costs of Prostate Cancer. Prostate 2010; 70: 1255-1264. https://doi.org/10.1002/pros.21161

[28] WAN Y, GAO X, MEHTA S, WANG Z, FARIA C et al. Indirect costs associated with metastatic breast cancer. J Med Econ 2013; 16: 1169-1178. https://doi.org/10.3111/1369699 8.2013 .826228

[29] ZAROGOULIDOU V, PANAGOPOULOU E, PAPAKOSTA D, PETRIDIS D, PORPODIS K et al. Estimating the direct and indirect costs of lung cancer: a prospective analysis in a Greek University Pulmonary Department. J Thorac Dis 2015; 7: S12-19. https://doi.org/10.3978/j.issn.20721439.2015.01.57

[30] ROBINSON D JR, ORLOWSKI RZ, STOKES M, HE J, HUSE $S$ et al. Economic Burden of Relapsed or Refractory Multiple Myeloma: Results from an International Trial. Eur J Haematol 2017; 99: 119-132. https://doi.org/10.1111/ejh.12876

[31] WANG Z, YUAN H, ROTH M, STARK JM, BHATIA R et al. SIRT1 deacetylase promotes acquisition of genetic mutations for drug resistance in CML cells. Oncogene 2013; 32: 589-598. https://doi.org/10.1038/onc.2012.83

[32] [ACT NO. 461/2003 COLL., ON SOCIAL INSURANCE] https://www.slov-lex.sk/static/pdf/2003/461/ ZZ_2003_461_20210101.pdf [As accessed on January 20, 2021]

[33] JÖNSSON B, HOFMARCHER T, LINDGREN P, MOEN F, WILKING N. (Eds.) Comparator report on patient access to cancer medicines in Europe revisited. The Swedish Institute for Health Economics (IHE) Report, Lund 2016. https://ihe. se/en/publicering/oncology-comparator-report-uk/

[34] BLOMQVIST P, LYCKE J, STRANG P, TÖRNQVIST H, EKBOM A. Brain tumours in Sweden 1996: care and costs. J Neurol Neurosurg Psychiatry 2000; 69: 792-798. https://doi. org/10.1136/jnnp.69.6.792 
[35] BROEKX S, HOND ED, TORFS R, REMACLE A, MERTENS $\mathrm{R}$ et al. The costs of breast cancer prior to and following diagnosis. Eur J Health Econ 2011; 12: 311-317. https://doi.org/10.1007/s10198-010-0237-3

[36] TINGSTEDT B, ANDERSSON E, FLINK A, BOLIN K, LINDGREN B et al. Pancreatic cancer, healthcare cost, and loss of productivity: a register-based approach. World J Surg 2011; 35: 2298-2305. https://doi.org/10.1007/s00268-0111208-2

[37] HANLY P, TIMMONS A, WALSH PM, SHARP L. Breast and prostate cancer productivity costs: a comparison of the human capital approach and the friction cost approach. Value Health 2012; 15: 429-436. https://doi.org/10.1016/j. jval.2011.12.012

[38] HANLY P, WALSH PM, O CEILLEACHAIR A, SKALLY M, STAINES A et al. Work-related productivity losses in an era of ageing populations: the case of colorectal cancer. J Occup Environ Med 2013; 55: 128-134. https://doi.org/10.1097/ JOM.0b013e3182820553

[39] ORTEGA-ORTEGA M, OLIVA-MORENO J, JIMÉNEZAGUILERA JDE D, ROMERO-AGUILAR A, ESPIGADOTOCINO I. Productivity loss due to premature mortality caused by blood cancer: a study based on patients undergoing stem cell transplantation. Gac Sanit 2015; 29: 178-183. https://doi.org/10.1016/j.gaceta.2015.01.010

[40] HANLY P, SHARP L. The cost of lost productivity due to premature cancer-related mortality: an economic measure of the cancer burden. BMC Cancer 2014; 14: 224. https://doi. org/10.1186/1471-2407-14-224

[41] EUROPEAN SOCIETY FOR MEDICAL ONCOLOGY. The burden and cost of cancer. Ann Oncol 2007;18: iii8-22. https://doi.org/10.1093/annonc/mdm097

[42] BRADLEY CJ, YABROFF KR, DAHMAN B, FEUER EJ, MARIOTTO A et al. Productivity costs of cancer mortality in the United States: 2000-2020. J Natl Cancer Inst 2008; 100: 1763-1770. https://doi.org/10.1093/jnci/djn384

[43] LUENGO-FERNANDEZ R, LEAL J, GRAY A, SULLIVAN $\mathrm{R}$ et al. Economic burden of cancer across EU: a populationbased a cost analysis. Lancet Oncol 2013; 14: 1165-1174. https://doi.org/10.1016/S1470-2045(13)70442-X

[44] TINGSTEDT B, WEITKÄMPER C, ANDERSSON R. Early onset pancreatic cancer: a controlled trial. Ann Gastroenterol 2011; 24: 206-212.

[45] JAYADEVAPPA R, SCHWARTZ JS, CHHATRE S, GALLO JJ, WEIN AJ et al. The burden of out-of-pocket and indirect costs of prostate cancer. Prostate 2010; 70: 1255-1264. https://doi.org/10.1002/pros.21161

[46] TENNVALL GR, PERSSON U, NILSSON B. The economic costs of acute myeloid leukemia in Sweden. Int J Technol Assess Health Care 1994; 10: 683-694. https://doi.org/10.1017/ s0266462300008266

[47] REIS A, IHLE P, PAULUS U, FERBER LV, DIEHL V et al. Cost of illness of malignant lymphoma in Germany. Eur J Cancer Care (Engl) 2006; 15: 379-385. https://doi. org/10.1111/j.1365-2354.2006.00676.x

[48] BLANKART CR, KOCH T, LINDER R, VERHEYEN F, SCHREYÖGG J et al. Cost of illness and economic burden of chronic lymphocytic leukemia. Orphanet J Rare Dis 2013; 8: 32. https://doi.org/10.1186/1750-1172-8-32
[49] HANLY P, SOERJOMATARAM I, SHARP L. Measuring the societal burden of cancer: the cost of lost productivity due to premature cancer-related mortality in Europe. Int J Cancer 2015; 136: E136-145. https://doi.org/10.1002/ijc.29105

[50] [IN HEALTHCARE. (Eds.)] [ÚDZS accepted 123,196 registered for a change in the health insurance company] SITA a.s., 2018. https://vzdravotnictve.sk/udzs-akceptoval-123196-prihlasok-na-zmenu-zdravotnej-poistovne/ [As accessed on November 23, 2018]

[51] MORRIS S, DEVLIN N, PARKIN D, SPENCER A. (Eds.) Economic analysis in health care. Wiley, 2007, p.400. ISBN 978-0-470-01685-5

[52] REGISTRY OF MONOCLONAL GAMMOPATHIES (RMG REGISTRY), Institute of Biostatistics and Analyses (IBA), https://opencpu.biostatistika.cz/sample-apps/RMGvizualizace/

[53] INSTITUTE OF HEALTH POLICIES, Ministry of Health of Slovak Republic, 2018. http://www.health.gov.sk/?Instituteof-Health-Policies [As accessed on August, 2018]

[54] WORLD HEALTH ORGANISATION (WHO), ICD Classifications. https://icd.who.int/browse11/l-m/en\#/ http\%3a\%2f\%2fid.who.int\%2ficd\%2fentity\%2f1766440644 [As accessed on December 05, 2018]

[55] WORLD HEALTH ORGANIZATION (Eds.). World health statistics 2012. World Health Organization, 2012, p.176. ISBN 9789241564441. https://apps.who.int/iris/handle/10665/44844

[56] YONG K, DELFORGE M, DRIESSEN C, FINK L, FLINOIS A et al. Multiple myeloma: patient outcomes in real-world practice. Br J Haematol 2016; 175: 252-264. https://doi. org/10.1111/bjh.14213

[57] [ACT NO. 191/2018 COLL., changing and amending ACT NO. 447/2008 COLL] https://www.slov-lex.sk/pravne-predpisy/SK/ZZ/2018/191/ [As accessed on December 05, 2018]

[58] GARDNER JW, SANBORN JS. Years of potential life lost (YPLL)--what does it measure? Epidemiology 1990; 1: 322329. https://doi.org/10.1097/00001648-199007000-00012

[59] VAN DEN HOUT WB. The value of productivity: humancapital vs. friction-cost method. Ann Rheum Dis 2010; 69: i89-91. https://doi.org/10.1136/ard.2009.117150

[60] GROSSMAN M. On the concept of health capital and the demand for health. J Polit Econ 1972; 80: 223-255. https:// www.jstor.org/stable/1830580?seq=1\#metadata_info_tab_ contents

[61] MINISTRY OF FINANCE OF SLOVAK REPUBLIC (MFSR). [Development of relevant indicators for 2016 and 2017 and forecast for 2018.] MFSR, Bratislava 2018. https://

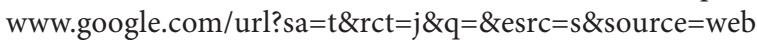
\&cd=\&ved=2ahUKEwj0sMavhqjuAhWFuIsKHYMQBGU QFjAAegQIARAC\&url=https\%3A\%2F\%2Frokovania.gov. sk\%2Fdownload.dat\%3Fid\%3D7CD0E78DEEDD4A2D87 6244AFED8EC70D-E8AF0B6154D1E46A5D77073F436D DE05\&usg=AOvVaw3KtRpfd8oE39MN83TXf69n [As accessed on July 24, 2018]

[62] [HEALTH STATISTICS YEARBOOK OF THE SLOVAK REPUBLIC 2018.] [National health information center], Bratislava 2018. ISBN 978-80-89292-13-4 [As accessed on December, 2018] 
[63] LUDWIG H, DURIE BGM, BOLEJACK V, TURESSON I, KYLE RA et al. Myeloma in patients younger than age 50 years presents with more favorable features and shows better survival: an analysis of 10549 patients from the International Myeloma Working Group. Blood. 2008; 111(8): 4039-4047. https://doi.org/10.1182/blood-2007-03-081018

[64] KUMAR SK, DISPENZIERI A, LACY MQ, GERTZ MA, BUADI FK et al. Continued improvement in survival in multiple myeloma: changes in early mortality and outcomes in older patients. Leukemia 2014; 28: 1122-1128. https://doi. org/10.1038/leu.2013.313

[65] WILDES TM, ROSKO A, TUCHMAN SA. Multiple Myeloma in the Older Adult: Better Prospects, More Challenges. J Clin Oncol 2014; 32: 2531-2540. https://doi.org/10.1200/ JCO.2014.55.1028

[66] RAJKUMAR SV, DISPENZIERI A. Multiple myeloma and related disorders. In: Niederhuber JE, Armitage JO, Doroshow JH, Kastan MB, Tepper JE (Eds.). Abeloff's Clinical Oncology, 5th Edition, Elsevier, Philadelphia 2013. ISBN 9780323222112

[67] CANCER RESEARCH UK, Myeloma survival statistics: One-, five- and ten-year survival for myeloma. Cancer Research UK, 2018. https://www.cancerresearchuk.org/healthprofessional/cancer-statistics/statistics-by-cancer-type/myeloma/survival\#heading-Zero

[68] THE SLOVAK MYELOMA SOCIETY, Recomendations for multiple myeloma. http://myelom.sk/experts-section.html [As accessed on October, 2018]

[69] [SOCIAL INSURANCE AGENCY.] [Average sickness benefits/1 case.] https://www.socpoist.sk/priemerne-vysky-nemocenskych-davok-1pripad/1622s [As accessed on December, 2018]

[70] [SOCIAL INSURANCE AGENCY.] [Average amounts of pension benefits for valorisation purposes.] https://www. socpoist.sk/priemerne-vysky-dochodkovych-davok-prepotreby-valorizacie--k-306-/56026s [As accessed on December, 2018]
[71] [ACT NO. 43/2004 COLL., on Pensionary Savings.] https://www.slov-lex.sk/static/pdf/2004/43/ ZZ_2004_43_20210101.pdf [As accessed on December, 2018]

[72] EUROSTAT: Life expectancy by age and sex. Eurostat, 2018. https://appsso.eurostat.ec.europa.eu/nui/show. do?dataset=demo_mlexpec\&lang=en [As accessed on July 09, 2018]

[73] FONSECA R, ABOUZAID S, BONAFEDE M, CAI Q, PARIKH K et al. Trends in overall survival and costs of multiple myeloma, 2000-2014. Leukemia 2017; 31: 1915-1921. https://doi.org/10.1038/leu.2016.380

[74] BURNS R, LEAL J, SULLIVAN R, LUENGO-FERNANDEZ R. Economic burden of malignant blood disorders across Europe: a population-based cost analysis. Lancet Haematol 2016; 3: e362-370. https://doi.org/10.1016/S23523026(16)30062-X

[75] [COUNCIL FOR BUDGET RESPONSIBILITY.] [Calculation of Retirement Age.] http://www.rozpoctovarada.sk/svk/ rozpocet/300/vypocet-dochodkoveho-veku [As accessed on November 20, 2020]

[76] [SOCIAL INSURANCE AGENCY] [Retirement Age in 2017 and 2018.] https://www.socpoist.sk/dochodkovy-vekod-roku-2017-acu/69036s [As accessed on December, 2018]

[77] GOODWIN JA, COLEMAN EA, SULLIVAN E, EASLEY R, MCNATT PK et al. Personal financial effects of multiple myeloma and its treatment. Cancer Nurs 2013; 36: 301-308. https://doi.org/10.1097/NCC.0b013e3182693522

[78] [STATISTICAL OFFICE OF THE SLOVAK REPUBLIC. (Eds.)] [Employees and average monthly wage in 2017]. Štatistický úrad Slovenskej republiky 2018, ISBN 1978-808121-626-8 (online)

[79] [ACT NO. 311/2001 COLL., Labour Act.] https://www.slovlex.sk/static/pdf/2001/311/ZZ_2001_311_20210101.pdf [As accessed on January 20, 2021]

[80] PEARCE A, BRADLEY C, HANLY P, O'NEILL C, THOMAS AA et al. Projecting productivity losses for cancer-related mortality 2011-2030. BMC Cancer 2016; 16: 804. https://doi. org/10.1186/s12885-016-2854-4 